\title{
Sprawa Zygmunta Wasilewskiego - proces o zniesławienie Aleksandra Lednickiego
}

W dniu 20 stycznia 1920 roku, w dwudziestym numerze,, Gazety Warszawskiej”, wychodzącej pod redakcją polityka związanego z Narodową Demokracją Zygmunta Wasilewskiego ${ }^{1}$, ukazała się bardzo krótka notatka zatytułowana Pod adresem Ministerium Sprawiedliwości. Jej autor przypisywał Aleksandrowi Lednickiemu jednemu $z$ najwybitniejszych polskich adwokatów w okresie Cesarstwa Rosyjskiego, liderowi moskiewskiej Polonii, dawnemu prezesowi Komisji Likwidacyjnej do spraw Królestwa Polskiego działającej przy rosyjskim Rządzie Tymczasowym² ${ }^{2}$, dopuszczenie

1 U. Jakubowska, Rola Zygmunta Wasilewskiego $w$ obozie narodowym, [w:] Narodowa Demokracja XIX-XXI wiek (Koncepcje-ludzie-działalność), red. T. Sikorski i A. Wątor, Szczecin 2008, s. 643-644; Z. Wasilewski, Pokolenia $w$ służbie narodu, Londyn 1962, s. 24-25; R. Wapiński, Narodowa Demokracja 1893-1939. Ze studiów nad dziejami myśli nacjonalistycznej, Wrocław-Warszawa-Kraków-Gdańsk 1980, s. 22; 74-75; W. Studnicki, Pisma wybrane, t. I, Z przeżyć i walk, Toruń 2000, s. 97.

2 Z. Ponarski, Wokót sprawy polskiej na Wschodzie, Torun 2003, s. 24-50; W. Lednicki, Aleksander Lednicki (oszczerstwa i prawda), Zeszyty Historyczne, I, Paryż 1962, s. 67-92; A. Lednicki, Pamiętniki 1914-1918, Kraków 1994, s. 5-19; A. Garlicki, Józef Piłsudski 1867-1935, Kraków 2008, s. 1032; M. Mroczko, Stanisław Kozicki (1876-1958). Biografia polityczna, Gdańsk 1999, s. 62; W. Pobóg-Malinowski, Najnowsza historia polityczna Polski, t. 2, 1914-1939, Kraków 2004, s. 94; W. Grabski, Dwa lata pracy u podstaw państwowości naszej 1924-1925, oprac. M.M. Droz- 
się zdrady głównej wobec państwa polskiego oraz usiłowanie ucieczki z kraju przed grożącą mu odpowiedzialnością karną ${ }^{3}$ Na łamach periodyku pisano: „Dowiadujemy się z pewnego źródła, że p. Aleksander Lednicki, który dopuścił się czynu zdrady głównej, zamierza w sobotę [...] 24 b.(ieżącego) m.(iesiąca) wyjechać do Rzymu. List p. Lednickiego noszący wszelkie cechy zdrady wobec państwa polskiego, znany jest p. Ignacemu Szebece i innym ludziom, których on może wskazać. Dowodem, że czyn p. Lednickiego jest powszechnie znany, może być fakt, że postanowiono usunąć go $z$ szeregu instytucji [...]. Żądamy wobec tego od Ministerium Sprawiedliwości, którego obowiązkiem jest dopilnować ukarania winy, aby wdało się $\mathrm{w}$ tę sprawę i nie dopuściło do ucieczki p.(ana) Lednickiego przed karzącym ramieniem sprawiedliwości”4. Po ukazaniu się tej informacji Aleksander Lednicki 11 lutego 1920 roku złożył do Wydziału III Karnego Sekcji IX Sądu Okręgowego w Warszawie skargę 5 .

W związku z tym, że był to artykuł redakcyjny, główną odpowiedzialność za jego treść ponosił redaktor naczelny pisma. Dlatego też Lednicki domagał się pociągnięcia Zygmunta Wasilewskiego do odpowiedzialności karnej za pomówienie. Pełnomocnik Lednickiego, adwokat Bronisław Sobolewski ${ }^{6}$, powoływał się na artykuły 531 i 533 rosyjskiego kodeksu karnego (dalej KK), które pojęcie zniesławienia, co należy podkreślić, traktowały bardzo ogólnikowo, pozo-

dowski, Warszawa-Rzeszów 2003, s. 18, 48, 356; W. Wojdyło, Stanisław Grabski (1871-1949). Biografia polityczna, Torun 2003, s. 147-148; N. Davies, Orzet Biały, Czerwona Gwiazda. Wojna polsko-bolszewicka 1919-1920, Kraków 2009, s. 46; A. Chwalba, Polacy w służbie Moskali, Warszawa-Kraków 1999, s. 243.

${ }^{3}$ Do Pana Prokuratora przy Sądzie Okręgowym $w$ Warszawie, [w:] Akta sędziego śledczego Sądu Okręgowego $w$ Warszawie, mszp., Archiwum Aleksandra Lednickiego, sygn. 60/88, Biblioteka Jagiellońska w Krakowie (BJ), k. 8 .

${ }^{4}$ Pod adresem Ministerium Sprawiedliwości, Gazeta Warszawska, Warszawa 20 I 1920, nr 20, s. 4.

${ }^{5}$ E. Śmiarowski, Mowy obrończe (1920-1925), Warszawa 1926, s. 142.

${ }^{6}$ Zob. Pełnomocnictwo procesowe, [w:] Akta sędziego śledczego Sądu Okręgowego $w$ Warszawie, k. 9. 
stawiając sądowi szeroką ocenę wypowiedzianych stwierdzeń ${ }^{7}$. Skarga została doręczona Wasilewskiemu 12 marca 1920 roku. Dnia 20 marca pełnomocnik redaktora „Gazety Warszawskiej”, mecenas Stanisław Kijeński ${ }^{8}$, skierował do sądu podanie, w którym podał listę dwudziestu czterech świadków, którzy „stwierdzą, że rozgłoszone w zaskarżonym artykule [...] okoliczności są prawdziwe i redaktor Wasilewski miał dostateczne zasady do ich rozgłoszenia”' Postępowanie zostało wszczęte 22 kwietnia 1920 roku przez prokuratora działającego przy sądzie okręgowym, który akta sprawy, zgodnie $\mathrm{z}$ postanowieniem sądu z 6 kwietnia 1920 roku, przesłał do sędziego śledczego ${ }^{10}$. Po wstępnym zapoznaniu się $z$ dokumentacją sprawy sędzia śledczy zaproponował Lednickiemu i Wasilewskiemu pojednanie, co było zgodne $z$ art. 303 rosyjskiej ustawy postępowania karnego (dalej UPK). Próba ta okazała się jednak bezskuteczna. Wasilewski, nie przyznając się do winy, argumentował wówczas, że

7 Z. Ponarski, op.cit., s. 223.

8 E. Muszalski, Stanisław van der Noot Kijeński (Kijański), [w:] Polski Słownik Biograficzny, t. XII, Wrocław-Warszawa-Kraków 1966-1967, s. 449-450; zob. P. Dąbrowski, Zabójstwo Prezydenta Gabriela Narutowicza - proces Eligiusza Niewiadomskiego, Imponderabilia. Biuletyn Piłsudczykowski, z. 2, Gdańsk 2011, s. 155-163; Stanisław Kijeński był obrońcą z urzędu Eligiusza Niewiadomskiego, sądzonego o zabójstwo prezydenta Gabriela Narutowicza.

9 Do Saqdu Okręgowego $w$ Warszawie Wydział VIII Karny $w$ sprawie nr 137/20, [w:] Akta sędziego śledczego Sądu Okręgowego w Warszawie, k. 23-23v; na świadków wskazani zostali: 1. Antoni Żwan; 2. Andrzej Niemojewski - poeta, pisarz okresu Młodej Polski; 3. inżynier Tadeusz Zieliński; 4. hrabia Józef Miączyński; 5. hrabia Ksawery Pusłowski; 6. Władysław Glinka - prezes Komitetu Towarzystwa Kredytowego Ziemskiego; 7. kapitan Mieczysław Wężyk; 8. Mieczysław Radwan; 9. Władysław Rabski; 10. Józef Kożuchowski; 11. doktor Jan Załuska - poseł; 12. Adolf Nowaczyński; 13. Fryderyk Jurjewicz; 14. Stanisław Gurbski; 15. Eryk Kurnatowski; 16. ksiądz Kazimierz Lutosławski - poseł; 17. Antoni Marylski-Łuszczewski - poseł; 18. książę Seweryn Czetwertyński - poseł; 19. Ignacy Szebeko - deputowany polski w Berlinie; 20. hrabia Władysław Sobański - poseł polski w Brukseli; 21. Władysław Michejda - adwokat w Cieszynie; 22. kapitan Henryk Bagiński; 23. pułkownik Tadeusz Żółkiewski; 24. Aleksander Świętochowski - pisarz, publicysta, historyk i filozof.

10 Akta sędziego śledczego Sądu Okręgowego w Warszawie, k. 5. 
wszelkie wiadomości zawarte w styczniowej publikacji pochodziły z czasopisma „Myśl Niepodległa” i tym samym żadnych zarzutów Lednickiemu nie stawiał ${ }^{11}$. Po tym oświadczeniu oskarżyciel prywatny został wezwany do wskazania swojej listy świadków w sprawie $^{12}$, co stało się jednak niemożliwe $z$ uwagi na wyjazd Lednickiego do Rzymu. Ostatecznie sędzia śledczy 22 kwietnia 1920 r. wszczął wstępne śledztwo i tym samym rozpoczął przesłuchiwanie świadków oskarżonego. Czynności te trwały niemalże trzy lata ${ }^{13}$. Zeznania świadków dotyczyły trzech momentów działalności Aleksandra Lednickiego, mianowicie: a) kwestii formowania wojska polskiego w Rosji, której Lednicki, wbrew interesom narodowym, był przeciwny; b) jego rzekomego pośredniczenia pomiędzy Niemcami a liberalnym Rządem Tymczasowym w Rosji (utworzonym w 1917 roku w wyniku rewolucji lutowej, na czele którego początkowo stał książę Gieorgij Jewgieniewicz Lwow, a od 21 lipca Aleksander Kiereński) na rzecz zawarcia odrębnego traktatu pokojowego, z pokrzywdzeniem przyszłego państwa polskiego; c) proniemieckiego stanowiska Lednickiego, które wyrażał w czasie reprezentowania Rady Regencyjnej w Moskwie, dowodem czego miał być jego list skierowany do niemieckiego komisarza władz okupacyjnych hrabiego Hugona von Lerchenfeld-Köfferinga ${ }^{14}$, rzekomo zawierający denuncjację udających się do Murmańska polskich żołnierzy i oficerów ${ }^{15}$.

Jednocześnie w maju 1920 roku redakcja „Gazety Warszawskiej” przytoczyła treść datowanego na 25 grudnia 1918 roku listu Michała Iwanowicza Tereszczenki - byłego ministra finansów oraz ministra spraw zagranicznych Rządu Tymczasowego ${ }^{16}$, do Ignacego Albertowicza Szebeki - londyńskiego delegata Komitetu Narodowego Polskiego w Paryżu, posła polskiego w Berlinie. Korespondencja ta

11 Protokót pojednania, [w:] ibidem, k. 13.

12 Zawiadomienie oskarżyciela prywatnego, [w:] ibidem, k. 19.

13 Szerzej zob. Protokoły przesłuchań, [w:] ibidem, k. 28-66.

14 Zob.: W. Suleja, Tymczasowa Rada Stanu, Warszawa 1998, s. 43, 46-48, 51, 55.

15 E. Śmiarowski, op.cit., s. 142.

16 Zob.: R. Pipes, Rewolucja rosyjska, Warszawa 2006, s. 315, 426; L. Bazylow, P. Wieczorkiewicz, Historia Rosji, Wrocław-Warszawa-Kraków 2005, s. 377, 379 . 
miała rudymentarne znaczenie dla przebiegu późniejszego postępowania. Jego autor stwierdził, że po powrocie Lednickiego ze Sztokholmu, w drugiej połowie 1917 roku, gdzie brał udział w konferencji polskich działaczy politycznych, spotkał się z nim późnym wieczorem w gabinecie ministerstwa spraw zagranicznych. Lednicki miał zdać wówczas sprawozdanie $z$ wyjazdu do stolicy Szwecji. Szczegółowo ukazał rolę, jaką odegrał w zjeździe hrabia Wojciech Hilary Rostworowski - wówczas członek Tymczasowej Rady Stanu w Warszawie, który w opinii Lednickiego przybył jako pełnomocnik rządu niemieckiego. Tereszczenko pisał: „Stąd rozmowa zeszła na sytuację w Niemczech, a Lednicki, powtarzając jakoby to, co słyszał, począł dowodzić, że Niemcy zdają sobie sprawę $z$ konieczności zawarcia najrychlejszego pokoju, ale że i dla Rosji dalszy udział w wojnie staje się samobójstwem, że wiadomo mu, iż państwa centralne zgodziłyby się pójść w układy z Rosją na warunkach bardzo dogodnych, których Rosja nie osiągnęłaby nawet w razie t. zw. paix blanche [białego pokoju - bez przegranych i zwycięzców, bez aneksji bądź odszkodowań - P.D.], stanowiącego jedyną obecnie możliwość zakończenia wojny. Rostworoskiemu znane są te warunki. I wyjąwszy z kieszeni notes, Lednicki odczytał mi z niego kilka oderwanych notatek: przywrócenie dawnych (do r. 1914) granic, przyłączenie części Galicji Wschodniej, układ opowiadający interesom Rosji w sprawie cieśnin, autonomiczność w sprawie umów handlowych". Po wysłuchaniu Lednickiego jego interlokutor stwierdził, że udzielił mu paszportu dyplomatycznego w zupełnie innych sprawach i tym samym nie dał mu pełnomocnictw do prowadzenia rozmów na tak ważne tematy. Znamiennym był fakt, że Lednicki następnie miał udać się z tymi informacjami do prezesa Rady Ministrów Aleksandra Kiereńskiego, który w słowach skierowanych do Tereszczenki stwierdził: „Skąd mu przyszło do głowy faktorować między nami a Niemcami?" ${ }^{17}$. Z treści nie wynikało jednoznacznie, że Lednicki opowiadał się za zawarciem odrębnego, „separatywnego” pokoju pomiędzy Rosją a Niemcami. Zgodnie z przyjętym założe-

17 List Tereszczenki do I. Szebeki, dat. 25 XII 1918, [w:] Z. Wasilewski, Proces Lednickiego. Fragment z dziejów odbudowy Polski 1915-1924, Warszawa 1924, s. 104. 
niem miał jedynie przekazać wiadomości, które usłyszał w trakcie pobytu w Sztokholmie, a mogące mieć znaczenie dla państwa rosyjskiego. Według redakcji wynikało $z$ niego, że Lednicki działał w pierwszej wojnie światowej w interesie Niemiec, popierając program zwrócenia Rosji ziem polskich i oddania Galicji Wschodniej. Występował przeciwko, powołując się na swoje wpływy w rządzie rosyjskim, utworzeniu armii polskiej opozycyjnej wobec państwa niemieckiego ${ }^{18}$. W innym miejscu zaznaczano: „Lednicki był w Rosji kierownikiem wielkiego spisku, który ogarnął Europę pod hasłem pokoju niemieckiego". Do tego nakłaniał także rząd rosyjski, aby uznał Radę Stanu i Radę Regencyjną i wycofał Rosję z wojny, jak i pragnął stanąć na czele polskiego przedstawicielstwa za granicą, pod warunkiem upadku Komitetu Narodowego Polskiego Romana Dmowskiego ${ }^{19}$. Był przedstawicielem tak zwanej Polski neutralnej, mającej służyć za pomost do zgody między stronami wojującymi, w pierwszym rzędzie między Polską a państwami centralnymi ${ }^{20}$. Na koniec stwierdzano: „P. Lednicki, któremu nawet w Rosji nauczono się wreszcie nie wierzyć w niczym, a jest to przecież kraj nieprawdopodobieństw umysłowych, zbyt wiele liczy na naiwność Warszaw”21.

Dnia 29 marca 1923 roku sędzia śledczy drugiego okręgu miasta stołecznego Warszawy zgodnie $z$ artykułami: 448 oraz 476 UPK wezwał Wasilewskiego, w celu ewentualnego uzupełnienia akt śledztwa. Redaktor „Gazety Warszawskiej” nie wniósł żadnych zastrzeżeń i tym samym postępowanie, w oparciu o art. 478 i 479 UPK, zostało skierowane 30 marca do podprokuratora przy Sądzie Okręgowym w Warszawie ${ }^{22}$. W maju 1923 roku strony postępowania zostały

18 Udział Al. Lednickiego $w$ pośrednictwie na rzecz Niemiec, Gazeta Warszawska 13 V 1920, nr 129, s. 1; zob.: Pax germanica i pośrednictwo A.R. Lednickiego, cz. I, Gazeta Warszawska 20 V 1920, nr 136, s. 6-7; Pax germanica i pośrednictwo A.R. Lednickiego, cz. II, Gazeta Warszawska 21 V 1920, nr 137, s. 6-7.

19 COR. (sygn. nierozwiązana), Pp. Askenazy i Zaleski, cz. I, Gazeta Warszawska 16 III 1922, nr 75, s. 2.

20 Przypomnienie, Gazeta Warszawska 9 I 1924, nr 9, s. 1.

21 Pax germanica i pośrednictwo A.R. Lednickiego, cz. III, Gazeta Warszawska 23 V 1920, nr 139, s. 5.

22 Decyzja ostateczna, dat., Warszawa, 30 III 1923, [w:] Akta sędziego śledczego Sądu Okręgowego w Warszawie, k. 71. 
zawiadomione, że wszystkie akta sprawy wróciły do sądu. W dniu 1 czerwca 1923 roku pełnomocnik Aleksandra Lednickiego wniósł do sądu podanie o wezwanie osiemdziesięciu dwóch świadków ${ }^{23}$. Pierwszy termin rozprawy wyznaczono na 28 stycznia 1924 roku $^{24}$.

Sala Sądu Okręgowego w Warszawie była zapełniona tego dnia publicznością. Rozprawie, która rozpoczęła się o godz. 10.30, przewodniczył sędzia Jan Duda. Obok niego zasiedli: sędzia Emil Pęski i referent Aleksander Świątkowski. Aleksandra Lednickiego bronili adwokaci Eugeniusz Śmiarowski, Zygmunt Rudziński i Mieczysław Nagórski, Zygmunta Wasilewskiego zaś Stanisław Kijeński oraz Gustaw Zabłocki ${ }^{25}$. Na samym początku postępowania sędzia Pęski zaproponował stronom pojednanie, które jednak nie nastąpiło. Wasilewski do winy nie przyznawał się ${ }^{26}$, a wszystkie informacje zawarte w „Gazecie Warszawskiej”, ujawnił z uwagi na ciążący na nim „obowiązek publicystyczny”. Jednocześnie skład sędziowski poinformował strony, że nie stawiło się czterdziestu dwóch świadków wskazanych wcześniej. Mecenas Kijeński argumentował, że przy przesłuchiwaniu pozostałych należy zastosować art. 700 UPK, stanowiący, iż w pierwszej kolejności badani są świadkowie oskarżenia, a następnie oskarżonego. Taka sekwencja była o tyle ważna, że świadkowie obrony złożyli swoje zeznania już na etapie śledztwa ${ }^{27}$. Ripostował adwokat Śmiarowski, przypominając, iż logika procesu nakazywała stwierdzić, że to Lednicki był oskarżonym, ponieważ musiał obronić się przed zarzutami zawartymi w publikacji. Zaproponował, aby podzielić świadków na trzy zasadnicze kategorie, odpowiadające kluczowym etapom procesu w ustaleniu prawdy. Wymienił przy tym kwestie: a) listu Michała Tereszczenki do Ignacego Szebeki; b) korespondencji Lednickiego z Lerchenfel-

${ }^{23}$ Do Sądu Okręgowego w Warszawie, [w:] ibidem, k. 80-82v.

24 Z. Wasilewski, Proces Lednickiego, s. 110; łącznie przed ogłoszeniem wyroku odbyło się dwanaście posiedzeń.

25 Zob. E. Maj, Komunikowanie polityzne Narodowej Demokracji 1918-1939, Lublin 2010, s. 139.

26 Z. Wasilewski, Życiorys 1865-1939, mszp., BJ, sygn. przyb. 179/78, k. 82 .

27 Idem, Proces Lednickiego, s. 111-113. 
dem, a także c) sprawę wojskową ${ }^{28}$. Sąd zgodził się na takie przyjęcie trybu przesłuchiwania świadków. Od samego początku oskarżyciel starał się zakwestionować autentyczność listu Tereszczenki, ponieważ na rozprawie odczytano jedynie odpis, napisany na blankiecie Komitetu Narodowego Polskiego, opatrzony także jego pieczęcią i poświadczony przez Władysława Kubiaka. Finalnie sąd dopuścił dokument mający charakter pisma urzędowego jako dowód w sprawie ${ }^{29}$. Ignacy Szebeko zeznał, że w sierpniu 1917 roku przebywał w Sztokholmie. Lednicki przyjechał wówczas z Petersburga, gdzie piastował funkcję przewodniczącego Komisji Likwidacyjnej do spraw Królestwa Polskiego. Spotkali się celem wymiany różnych informacji, a przy rozmowie obecny był też Eustachy Dobiecki z Królestwa Polskiego. Lednicki, za pośrednictwem Szebeki, przywitał się także $z$ posłami państw sojuszniczych w Sztokholmie: francuskim, angielskim i włoskim. Świadek wyraził przekonanie, że wydawało mu się, iż Lednicki sprzyjał ogólnemu kierunkowi ścisłego sprzymierzenia się z Francją, Anglią i Włochami przeciwko państwom centralnym. W licznych rozmowach uczestniczył również Wojciech Rostworowski. Na początku 1918 roku do stolicy Szwecji przyjechał Tereszczenko, który spotkał się z Szebeką. Wyznał, że Lednicki sprawił mu „zawód”, ponieważ po powrocie ze Sztokholmu zaproponował zawarcie „separatywnego” pokoju z Niemcami, podając niezwykle korzystne jego warunki dla Rosji. Tereszczenko podkreślił w rozmowie z Szebeką, że Rząd Tymczasowy chciał dochować wierności państwom sprzymierzonym, dlatego propozycją Lednickiego był tym bardziej oburzony. Poseł poprosił, aby Tereszczenko opisał wszystko w skierowanym do niego liście. Szebeko następnie, w trakcie pobytu w Londynie, dał go do przeczytania Władysławowi Sobańskiemu, posłowi polskiemu w Brukseli, wówczas reprezentantowi Komitetu Narodowego Polskiego. Od tamtego momentu oryginału korespondencji już nie widział $^{30}$. Adwokaci w dalszej fazie przesłuchania chcieli uzyskać od świadka informację, czy warunki, które przedstawił Lednicki

\footnotetext{
28 Ibidem, s. 116-117.

29 Ibidem, s. 118-122.

30 Ibidem, s. 123-128.
} 
stanowiły jego koncept, czy też jedynie komunikował to, co usłyszał w trakcie pobytu w Sztokholmie. Szebeko powiedział, że Tereszczenko przedstawił to jako propozycję oskarżyciela.

Po dwugodzinnej przerwie niezwykle długie zeznania złożył Aleksander Lednicki. Zaczął od opisu spotkania z Szebeką na początku stycznia 1920 roku. $Z$ relacji Lednickiego wynikało, że nie znał wcześniej treści listu, a po zreferowaniu go przez Szebekę wyraził swoje oburzenie na zawarte w nim informacje. Domagał się jego upublicznienia, na co Szebeko odpowiedział: „Ja Panu nie radzę, daj Pan spokój. Oczywiście, w tym liście nie ma nic, co by mówiło o zdradzie z pańskiej strony, ale list zawiera w sobie takie oświetlenie sprawy, które dla Pana może być tylko przykre i kompromitujące”. Nie będąc pewnym zarzucanych mu czynów, 22 stycznia Lednicki wystosował List otwarty do społeczeństwa. Rozpoczął go słowami: „Przeszło od roku trwa bez przerwy przeciwko mnie zaciekła, napastliwa, w środkach nie przebierająca kampania”. Następnie, charakteryzując swoją orientację polityczną, konkludował, że w jego opinii Polska powinna prowadzić własną, niezależną od innych państw politykę. Miała być dostosowana do konkretnych warunków i możliwości ${ }^{31}$. Przypomniał o swoim mandacie w Radzie Regencyjnej, który „dawał [...] możność bronienia [...] rodaków zarówno od zagłady moralnej jako też od śmierci”. Pisał: „Sprawowanie tego mandatu było nieprzerwanym pasmem udręki, niebezpieczeństw, szykan ze strony sowietów i przeszkód ze strony niemieckiego poselstwa" 32 . W dalszej części zaznaczał, że opowiadał się przed 1918 rokiem za niepodległością Polski, która powinna była jedynie współpracować $z$ Rosją bez jakichkolwiek elementów serwilizmu, negując jednocześnie autonomiczny program lansowany przez kręgi Narodowej Demokracji ${ }^{33}$. W tym miejscu należy stwierdzić, że początkowo Lednicki był zagorzałym zwolennikiem

31 A. Lednicki, List otwarty, dat. 22 I 1920, [w:] ibidem, s. 89.

32 Ibidem, s. 92.

33 Zob. P. Dąbrowski, Narodowa Demokracja oraz krajowcy byłego Wielkiego Księstwa Litewskiego wobec kwestii autonomii Królestwa Polskiego na przełomie XIX i XX wieku, Czasopismo Prawno-Historyczne 2010, t. LXII, z. 2, s. 351-372. 
autonomii, organizując wielokrotnie w latach 1904-1906 zjazdy polsko-rosyjskie, na których popierano takie rozwiązanie sprawy polskiej ${ }^{34}$. W artykule zatytułowanym Mea culpa, opublikowanym 11 grudnia 1916 roku na łamach „Echa Polskiego”, a stanowiącym przejście na płaszczyznę niepodległościową, konstatował: „Mniemając, że tego, co szereg pokoleń utraciło, nie może jedno odzyskać, i ja byłem tego zdania, że w obecnej wojnie etapem w rozwoju życia Polski będzie zjednoczenie i że przyrzeczona przez Rosję, której szybkie odrodzenie będzie najważniejszą zdobyczą w tej wojnie, autonomia Polski jest jedyną realną konsekwencją zjednoczenia na zwycięstwie koalicji opartego [...]. Długie rozmyślanie nad biegiem wypadków utrwaliło mnie na stanowisku niepodległościowym. Trwający dotąd kryzys wewnętrzny w Rosji, tragizm współżycia, na stosunkach mechanicznych opartego, nie na sojuszu, zagarnięcie Polski przez Niemcy, ocena tego faktu i dążeń narodu polskiego przez prasę koalicyjną, francuską, i angielską, wszystko to torowało drogę programowi niepodległościowemu" ${ }^{35}$. W jego łamach ścierały się dwie koncepcje. Pierwsza $z$ nich zakładała, że rewolucja rosyjska doprowadzi do rozkładu w wojsku rosyjskim, co Polska powinna wykorzystać przez stworzenie własnej armii dla odzyskania ziem wschodnich. Druga zaś, tak zwana neutralna, opierała się na pokoju pomiędzy Rosją a państwami centralnymi, przyznającemu Polsce Królestwo Polskie oraz obszary znajdujące się pod okupacją niemiecką ${ }^{36}$.

Po powrocie $z$ Moskwy do Warszawy na Lednickiego spadły gromy, głównie ze strony Narodowej Demokracji, za rzekome pośredniczenie między Niemcami a Rosją, „topiące” tym samym sprawę polską. W kwestii formowania polskiej armii w Rosji w trakcie składania zeznań przypomniał o niewielkiej liczbie żołnierzy oraz nieprzychylności rządu rosyjskiego ${ }^{37}$. Dodał, że w maju 1917 r. delegaci pol-

34 J. Stefański, Aleksander Lednicki, [w:] Wybitni Polacy XIX wieku. Leksykon biograficzny, red. T. Gąsowski, Kraków 1998, s. 153.

35 Cyt. za: W. Studnicki, Pisma wybrane, t. III, Ludzie, idee i czyny, Toruń 2000, s. 212-213.

36 Ibidem, s. 217.

37 Zob. ibidem, s. 219. 
skich organizacji demokratycznych przywieźli do Sztokholmu protokół, z którego wynikało, że opinia publiczna w kraju była przeciwna tworzeniu formacji wojskowych będących przeciwstawieniem do Legionów Piłsudskiego, mogących w konsekwencji doprowadzić do bratobójczych walk między Polakami. Niemalże cała polska scena polityczna na emigracji w Rosji była podzielona na dwa zwalczające się obozy. Przypominał, że jako prezes Komisji Likwidacyjnej uzyskał w maju 1917 roku zezwolenie władz na zorganizowanie w Petersburgu zjazdu wojskowego Polaków, popierając przed Rządem Tymczasowym wyłoniony $\mathrm{w}$ trakcie spotkania Naczelny Komitet Wojskowy Polski jako legalną reprezentację polskiej siły zbrojnej. Prowadzenie akcji wojskowej pozostawił organizacjom wojskowym, nie angażując się dalej w partyjne rozgrywki ${ }^{38}$. Zaznaczył, że żadnego listu do hrabiego Lerchenfelda nie wystosował. Wyraził także ogromny żal z powodu listu Tereszczenki, ponieważ wielokrotnie stwierdzał, że „mądrość polityczna kierowników rządów sprzymierzonych koalicji anty-niemieckiej, nakazuje udzielić Polsce tych samych gwarancji, oraz zapewnień, jakie dano na początku wojny Serbom i Belgom”. Dodawał: „I tylko bezwstydnym nazwać należy twierdzenie, że mogłem być - na szkodę Polski pośrednikiem między Niemcami a Rosją"39. $Z$ kolei podczas jesiennej konferencji w Sztokholmie Lednicki zapewniał, iż zapoznał zebranych $z$ informacjami, że Rząd Tymczasowy Rosyjski nie porzuci koalicji i nie zawrze oddzielnego pokoju z Niemcami, tak niebezpiecznego dla Polski. Spotkał się także $z$ hrabią Rostworowskim, który zakomunikował mu, że według obserwacji warszawskich rząd rosyjski będzie zmierzał do zawarcia „separatywnego” pokoju na dogodnych dla siebie warunkach, nie troszcząc się o losy ziem położonych na wschód od przedwojennej granicy niemiecko-rosyjskiej $^{40}$. Lednicki postanowił przekazać te wiadomości posłom państw sprzymierzonych oraz ministrowi Tereszczence i premierowi Kiereńskiemu ${ }^{41}$. Rozgoryczony atakiem na jego osobę, w niezwykle

\footnotetext{
38 A. Lednicki, List otwarty, s. 93-94.

39 Ibidem, s. 94.

40 J. Stefański, op.cit., s. 157.

41 A. Lednicki, List otwarty, s. 95-96.
} 
przejmujących słowach, na koniec listu konstatował: „Zdrowy rdzeń odradzającego się narodu polskiego jednak, niezadługo zrzuci z siebie wstrętny nalot tego pasożytnictwa moralnego i doprowadzi wreszcie do podniesienia naszych stosunków wewnętrznych tak, aby antagonizmy partyjne nie przejawiały się w sposób, budzący odrazę moralną u ludzi kulturalnych, nie wnosiły rozkładu w społeczeństwo, nie utrudniały pracy państwowej i zatruwały jadem nienawiści współżycie obywateli" ${ }^{42}$. Należy stwierdzić, że wszystkie informacje przedstawione przez Lednickiego zostały potwierdzone przez Wojciecha Rostworowskiego, który swoje oświadczenie opublikował na łamach „Gazety Warszawskiej”. Wynikało z niego jednoznacznie, że ostrzegł prezesa Komisji Likwidacyjnej o groźbie „separatywnego” pokoju. Pisał: „Odrębny pokój z Rosją musiał ziemie polskie, a więc Kresy i Kongresówkę oddać z powrotem Rosji, choćby $\mathrm{w}$ formie désinteresement niemieckiego i tę właśnie perspektywę p. Lednickiemu przedstawiłem" 43 . Wydaje się również, że premier Kiereński nie wierzył w złe intencje Lednickiego, czemu dał wyraz w liście skierowanym do jego syna Wacława. W trakcie spotkania w Londynie w 1918 roku miał oznajmić młodemu Lednickiemu, że był wdzięczny za wszystkie wiadomości przywiezione przez Aleksandra Lednickiego ze Sztokholmu, iż Niemcy poszukują drogi do zawarcia „separatywnego” pokoju, a także za kategoryczne oświadczenie, że Rząd Tymczasowy rosyjski nigdy na taką propozycję nie przystanie ${ }^{44}$.

Po opublikowaniu Listu otwartego, jak zaznaczył w trakcie przesłuchania Lednicki, wytoczył „Gazecie Warszawskiej” proces, a następnie podał się do dymisji ze wszystkich piastowanych stanowisk, to jest: prezesa Towarzystwa Wschodniego Społecznego Polskiego Związku Obrony Mienia Polaków Poszkodowanych w Rosji oraz członka Koła Prawników. Następnie wyjechał do Rzymu, gdzie

42 Zob. idem List otwarty, dat., 22 I 1921, mszp., Materiały Aleksandra Lednickiego, Polska Akademia Nauk. Archiwum w Warszawie (PAN. AW), sygn. III - 123, teczka 22, k. 21.

43 List W. Rostworowskiego, dat. 31 I 1920, [w:] Z. Wasilewski, Proces Lednickiego, s. 98.

44 W. Lednicki, 20 lat $w$ wolnej Polsce, Londyn 1973, s. 37-38. 
spotkał się z byłym deputowanym rosyjskiej Rady Państwa, posłem RP w Rzymie Konstantym Skirmuntem ${ }^{45}$ i Łysakowskim - wówczas ministrem rosyjskim przy Watykanie ${ }^{46}$. Po powrocie do Warszawy Związek Obrony Mienia zwołał Sąd Obywatelski, który uniewinnił Lednickiego i nie przyjął jego dymisji ${ }^{47}$. W jego składzie zasiadali także dwaj członkowie Sądu Najwyższego - Sawicki i Rymowicz ${ }^{48}$. W dalszej części przesłuchania wspominał o swoich spotkaniach z Tereszczenką i Kiereńskim, z którymi widział się przed wyjazdem do Sztokholmu. Zapewnili go, że nie może być mowy o jakimkolwiek „separatywnym” pokoju, a głównym celem rządu rosyjskiego było dążenie do zakończenia wojny wspólnie $z$ aliantami ${ }^{49}$. Wówczas także Lednicki skierował do Tereszczenki list, w którym prosił go o wskazówki w przedmiocie: a) pokoju i wojny, b) stosunku Rosji wobec Tymczasowej Rady Stanu. Minister odpowiedział jedynie na drugi z punktów, oznajmiając, że TRS będzie uznana w zależności od tego, czy zajmie definitywne stanowisko antyniemieckie. Bez konkretnych odpowiedzi Lednicki udał się do stolicy Szwecji. W trakcie podróży towarzyszyło mu wiele osób, w tym między innymi jego syn Wacław, książę Stanisław Lubomirski, Konstanty Lubomirski, Aleksander Tyszkiewicz oraz Jerzy Fedorowicz. Następnego dnia wyjechał także Aleksander Meysztowicz ${ }^{50}$. Na miejscu odbyło się wiele spotkań roboczych, a niektóre $z$ nich miały charakter jedynie kurtuazyjny. Lednicki zrelacjonował także poufną rozmowę $z$ Wojciechem Rostworowskim. Ten ostatni zapewnił go, że Niemcy zamierzają bądź już zaproponowały Rosji niezwykle korzystny pokój, na następujących warunkach: a) stworzenie państwa polskiego z Królestwa Polskiego i Galicji, b) przywrócenie granic z 1914 roku. Lednicki nie wierzył wypowiedzianym słowom, z uwagi na otrzymane wcześniej od Rządu Tymczasowego zapew-

45 Zob. M. Nowak-Kiełbikowa, Konstanty Skirmunt. Polityk i dyplomata, Warszawa 1998, s. 71-92.

46 Z. Wasilewski, Proces Lednickiego, s. 129-130.

47 Rosja i Niemcy $w$ sierpniu 1917. Dokumenty historyczne, Kurier Poranny 15 V 1920, s. 4.

48 Dzień polityczny, Gazeta Warszawska 30 IV 1920, nr 140, s. 3.

49 Z. Wasilewski, Proces Lednickiego, s. 131.

50 Ibidem, s. 133. 
nienia. Rostworowski miał oświadczyć: „Rosja jest w stanie rozkładu, [...] armia jest w bardzo złym stanie, [...] może być jakaś kombinacja, która w tym względzie ułatwia możliwość tego pokoju”. Nie wyraził również sprzeciwu, aby Lednicki poinformował o wszystkim stronę rosyjską, co też ten uczynił51.

Lednicki wspomniał także, że przed wyjazdem do Sztokholmu uznał za konieczne powołanie do życia przy prezesie Komisji Likwidacyjnej, specjalnej Rady wyłącznie do spraw Polaków przebywających w Rosji. Jednym $z$ przedmiotów jej działalności miała być kwestia Kościoła katolickiego. Wniosek został życzliwie przyjęty przez Rząd Tymczasowy, jednakże na jego tle doszło do rozłamu w szeregach samej Komisji Likwidacyjnej. Swój protest do Lednickiego wysłali członkowie Komisji: Seweryn Czetwertyński, Władysław Grabski, Jan Mrozowski i Jerzy Zdziechowski. Pisano: „Żal nam tej pracy konkretnej, realnej, którą rozpoczęliśmy, jednak ponad wszelkie względy obowiązków społecznych musimy stawiać przestrzeganie najważniejszej w życiu publicznym zasady: uczciwości politycznej. Nie możemy pozostawać w jakimkolwiek związku $z$ taka instytucją, która, pod pozorem pracy realnej i konkretnej likwidowania urzędów w Królestwie Polskim, staje się ośrodkiem polityki polskiej podporządkowanej nie woli narodu polskiego, a Pańskim widokom i opierającej swój autorytet na nominacji rządu obcego" 52. Jednocześnie sygnatariusze pisma, na znak sprzeciwu, złożyli swoje mandaty. W trakcie składania zeznań Lednicki wielokrotnie powtarzał, że czynił wiele zabiegów zmierzających do uznania stworzenia państwa polskiego jako jednego $z$ celów wojny. Spodziewał się, że mocarstwa sprzymierzone wydadzą akt stanowiący o przyszłej Polsce. Jednakże w trakcie obchodów kościuszkowskich, wyznaczonych na 3 października 1917 roku, swoje mowy wygłosili jedynie ambasadorowie francuski, angielski, amerykański i włoski. Żadne obietnice nie padły. Należy odnotować, że Lednicki sprzeciwiał się również powołaniu do życia, $z$ inicjatywy Ignacego Paderewskiego - przebywającego wówczas w Stanach Zjednoczo-

51 Ibidem, s. 135-136.

52 Protest. Do J.W. Pana Aleksandra Lednickiego, Prezesa Komisji Likwidacyjnej do spraw Królestwa Polskiego, [w:] ibidem, s. 101. 
nych Ameryki, Komitetu Narodowego Polskiego w Lozannie, będącego pewną namiastką rządu polskiego na emigracji. Lednicki opowiadał się za tym, aby trzon władzy wykonawczej znajdował się w Polsce, gdyż w przeciwnym razie mogło to zrodzić przykre konsekwencje dla sprawy polskiej. Po przewrocie bolszewickim Lednicki pozostał w Petersburgu. Usunięto go $\mathrm{z}$ zajmowanego stanowiska prezesa Komisji Likwidacyjnej, którą przekształcono na Naradę Ekonomiczną. Wkrótce powołano go na przedstawiciela Rady Regencyjnej w Petersburgu ${ }^{53}$. Następnie zeznawali Władysław Raczkiewicz, ksiądz biskup Zygmunt Łoziński, Stefan Filipkowski, Marian Raczyński oraz Maksymilian Hubert.

Drugi dzień rozprawy rozpoczął się 29 stycznia konfrontacją pomiędzy Wojciechem Rostworowskim a Lednickim. Wyjaśniano wiadomości zawarte w liście Tereszczenki oraz okoliczności spotkania między świadkami. Na późniejszych posiedzeniach sądu przesłuchiwano kolejne osoby (łącznie około stu), których zeznania w głównej mierze dotyczyły konferencji w Sztokholmie, działalności Tymczasowej Rady Stanu, formowania wojska polskiego, a także funkcjonowania Komisji Likwidacyjnej. Sąd pozyskał również informacje na temat członkostwa Lednickiego w przedstawicielstwie Rady Regencyjnej Królestwa Polskiego w Moskwie ${ }^{54}$, mającej sprawować opiekę nad obywatelami polskimi przebywającymi w Rosji oraz ich mieniem jak i zorganizować powrót wychodźców ${ }^{55}$. $Z$ faktem tym nierozerwalnie związana była kwestia listu Lednickiego do hrabiego Lerchenfelda, opublikowanego 21 listopada 1918 roku w moskiewskiej „Trybunie”, a znalezionego w mieszkaniu Lednickiego po przeprowadzonej przez bolszewików rewizji. Korespondencja ta, co należy podkreślić, była jedynie projektem, nigdy niewysłanym do adresata. Lednicki zaznaczał w nim, że znajduje się w Moskwie pod opieką niemieckiego przedstawicielstwa dyplomatycznego. Rząd rosyjski początkowo stał na stanowisku, że nie

\footnotetext{
53 Z. Wasilewski, Proces Lednickiego, s. 141.

54 W. Materski, Na widecie. II Rzeczpospolita wobec Sowietów 1918-1943, Warszawa 2005, s. 21.

55 Zob. T. Jędruszczak, Wstęp, [w:] Dokumenty z dziejów polskiej polityki zagranicznej 1918-1939, t. I, 1918-1932, Warszawa 1989, s. 6-7.
} 
będzie uznawał Rady Regencyjnej oraz jej dyspozytury, chyba że władze niemieckie zażądałyby tego, na co by przystano. Pisał także o trudnościach w piastowaniu urzędu i częstej niemocy w udzielaniu wsparcia Polakom. Podkreślał, że prasa polskich bolszewików szerzyła zaciekłą agitację wymierzoną w państwo polskie, rząd oraz Radę Regencyjną. Stwierdzał: „Podszczuwa ona masy przeciw Niemcom i przeciw porozumieniu polsko-niemieckiemu. Agenci sojuszników werbują Polaków dla sprawy koalicji i posyłają na Murman i do Czecho-Słowaków. Polskie przedstawicielstwo zaś, którego zadaniem byłoby przeciwdziałać tej idącej z dwu krańców, lecz ostatecznie zgodnej co do celu i skutku agitacji, wskazując na to, że w ramach porozumienia polsko-niemieckiego możliwą jest budowa państwa polskiego musi patrzeć na to, że wpływ jego na masy polskie niknie". Stąd też, wyznając potrzebę szczerego porozumienia $z$ rządami centralnymi, prosił posła niemieckiego o „użycie swego wpływu, aby praca w tym charakterze, w jakim została mu zakreślona przez Radę Regencyjną, była umożliwiona”56. Po opublikowaniu listu w stronę Lednickiego zostały skierowane zarzuty, że denuncjował tych obywateli polskich, którzy pomagali wojskowym Polakom w wyjeździe do Murmańska, a stamtąd do Francji w celu wzmocnienia armii polskiej walczącej z państwami centralnymi ${ }^{57}$. Władysław Studnicki na kartach swoich wspomnień zanotował: „List Lednickiego do hr. Lerchenfelda, bez względu na to czy był mu doręczony, czy też pozostał w archiwach Rady Regencyjnej - znajduje najzupełniejsze usprawiedliwienie w ówczesnej sytuacji politycznej. Lednicki dla ratowania uchodźców polskich musiał oprzeć się na Radzie Regencyjnej, musiał zostać jej przedstawicielem. Lecz Polska ówczesna nie wytworzyła jeszcze siły groźnej dla Rosji. Rosja chciała zignorować delegację Rady Regencyjnej, lecz nie mogła ignorować życzeń zwycięskich Niemiec. Dzięki ich rozkazowi rząd rosyjski uznał delegację Rady Regencyjnej i przez pewien czas umożliwił jej ratowanie Polaków w Rosji. Pragnąc mieć

56 List Lednickiego do Lerchenfelda, dat. IX 1918, [w:] Z. Wasilewski, Proces Lednickiego, s. 105-106.

57 Z. Wasilewski, Proces Lednickiego, s. 492. 
poparcie Niemiec, trzeba było wykazać, że to poparcie jest zgodne z niemiecką racją stanu"58. Ostatecznie Sąd Okręgowy w Warszawie wyrokiem z 11 lutego 1924 roku na mocy art. 537 ust. 2 KK uniewinnił Zygmunta Wasilewskiego, podając w uzasadnieniu, że „aczkolwiek w żadnym $z$ czynów Lednickiego, na które powołuje się oskarżony Wasilewski dla stwierdzenia słuszności swych zarzutów zdrady głównej i usiłowania ucieczki z kraju, uczynionych pod adresem Lednickiego, przewód sądowy znamion zdrady nie ustalił, a więc oskarżony Wasilewski dowodu prawdy nie przeprowadził, to jednak miał dostateczną podstawę do uważania rozgłoszonego zarzutu za prawdziwy i dopuścił się tego rozgłoszenia w interesie pełnionego przezeń obowiązku redaktora gazety, działając ze względów dobra publicznego i w poczuciu spełnianego przezeń obowiązku obywatelskiego". Sąd uznał, że Wasilewski swoje oskarżenie mógł oprzeć na liście Tereszczenki do Szebeki, a także na tym, iż Lednicki związany był politycznie $z$ Polskim Komitetem Demokratycznym, dążącym do porozumienia $z$ państwami centralnymi ${ }^{59}$. Dlatego też mimo nieprzeprowadzenia dowodu redaktor „Gazety Warszawskiej” działał w dobrej wierze i w wykonaniu ciężącego na nim obowiązku publicysty $^{60}$. Niewątpliwie orzeczenie zostało wydane $z$ rażącym naruszeniem prawa. Sędziowie nie dopatrzyli się jakichkolwiek znamion zniesławienia, mimo że Wasilewski nie potrafił udowodnić stawianemu Lednickiemu zarzutu zdrady głównej. Warto zauważyć, że po procesie przed Sądem Okręgowym w Warszawie, Roman Dmowski opublikował na łamach „Gazety Warszawskiej” około stu felietonów zatytułowanych Jak odbudować Polskę, poświęconych polityce polskiej w okresie pierwszej wojny światowej ${ }^{61}$, które w 1925 roku zostały zebrane i wydane w książce jego autorstwa zatytułowanej Polityka polska i odbudowanie państwa ${ }^{62}$.

58 W. Studnicki, Pisma wybrane, t. III, Ludzie, idee i czyny, s. 220.

59 Z. Wasilewski, Proces Lednickiego, s. 496-497.

60 E. Śmiarowski, op.cit., s. 143.

61 Z. Ponarski, op.cit., s. 11.

62 Z. Wasilewski, Pokolenia $w$ służbie narodu, s. 27; zob. R. Dmowski, Polityka polska i odbudowanie państwa, Warszawa 1926, s. 3-425. 
Obrona, nie zgadzając się z wyrokiem, wniosła 7 sierpnia 1924 r. skargę do sądu apelacyjnego. Adwokat Eugeniusz Śmiarowski dowodził, że wbrew argumentacji sądu okręgowego przewód sądowy ustalił, że oskarżony Zygmunt Wasilewski dopuścił się zarzuconego mu czynu nie w dobrej, lecz w złej wierze, kierowany nie interesem publicznym, a „prywatą partyjną”63. W niezwykle mocnych słowach pisał: „Jeżeli nasze życie publiczne nie ma zmienić się w grzęzawisko moralne, jeżeli w tym życiu mają obowiązywać jakieś zupełnie elementarne zasady etyki, jeżeli arena politycznej walki i ścierania się stronnictw nie ma stać się mordownią ludzi między sobą, w której każda broń, a więc równie dobrze potwarz jak sztylet, trucizna lub rewolwerowa kula, jest uznaną i do godności właściwego i legalnego środka walki podniesioną bronią, to Wasilewski winien był dowieść postawionego Lednickiemu zarzutu, albo odpokutować przewidzianą w kodeksie karą za krzywdę wyrządzoną człowiekowi oraz za sponiewieranie zasady moralnej, za zamach na zdrowie moralne narodu. Wasilewski prawdziwości zarzutu postawionego Lednickiemu nie dowiódł [...] mimo to [...] zostaje bezkarny, potwarca wychodzi $z$ sali sądowej w tryumfie, aby stwierdziwszy swoją bezkarność dalej prowadzić dzieło zniesławienia”" ${ }^{4}$. Sąd Okręgowy, w jego przekonaniu, wydając wyrok, odrywał się od płaszczyzny „niezmąconego obiektywizmu” i tym samym „dał się unieść politycznemu traktowaniu zagadnień ze stanowiska określonego politycznego kierunku”65. Wnosił jednocześnie o uchylenie zaskarżonego wyroku i skazanie oskarżonego za zniesławienie. Mecenas Stanisław Kijeński złożył replikę na skargę, domagając się jej oddalenia. Stwierdzał: „Zrobiono w procesie wszystko co można, aby sprawę zatopić w mętnych falach teorii i rekryminacji politycznych, a gdy Sąd zamiast, jak oczekiwano, ulęknąć się powodzi i zgłosić swoją moralną niekompetencję $z$ odwagą poszedł na te fale i pruł

63 Skarga apelacyjna, rkps, Materiały Aleksandra Lednickiego, PAN. AW, sygn. III - 123, teczka 22, k. 3c; zob. też Skarga apelacyjna, [w:] Akta sędziego śledczego Sądu Okręgowego w Warszawie, k. 172-179v.

64 Skarga apelacyjna, [w:] Akta sędziego śledczego Sądu Okręgowego $w$ Warszawie, k. 172v; E. Śmiarowski, op.cit., s. 143.

65 E. Śmiarowski, op.cit., s. 144. 
je, aby dotrzeć przez nie do jednostki i odnaleźć jej bezpośredni, moralny stosunek do narodu, to wtedy zagrała krew w rutynowym graczu politycznym i postanowił sędziów zatopić w odmętach. Taka jest logika tego manewru proceduralnego. Postanowiono Sąd Polski skompromitować zarzutem partyjności”. W opinii obrońcy Wasilewskiego skarga apelacyjna przypisywała redaktorowi „Gazety Warszawskiej” wyłącznie motywy polityczne (partyjne), płynące $z$ „zacietrzewienia", bez względu na prawdę historyczną oraz dobro narodu ${ }^{66}$. W dalszej części argumentował: „W stosunku do konkretnego faktu, jakim jest byt państwa w danych warunkach miejsca i czasu, jeżeli się rzecz rozważa pod kątem widzenia interesu tego państwa, chronionego przez kodeks karny, czyny swawolne Lednickiego musiały obudzić w każdym umiejącym czuć i myśleć obywatelu poważne zastrzeżenie"67.

Sąd apelacyjny na posiedzeniu odbytym 14 kwietnia 1925 roku, w składzie: przewodniczący sędzia Adam Kwiatkowski oraz sędziowie Kazimierz Wejtko i Witold Raczkiewicz, ponownie rozpoznał sprawę. Miesiąc później, w obecności podprokuratora przy sądzie apelacyjnym, ogłosił wyrok ${ }^{68}$. Sąd zgodził się $z$ motywami zaskarżonego orzeczenia, że Wasilewski nie przeprowadził dowodu prawdy, gdyż czyny zarzucane Lednickiemu nie zawierały cech zdrady i działania na szkodę państwa polskiego. Do rozstrzygnięcia pozostała jedynie kwestia dobrej bądź złej wiary oskarżonego i czy dopuścił się rozgłoszenia styczniowych informacji „gwoli pożytkowi państwowemu lub społecznemu, albo w interesie pełnionego przezeń obowiązku redaktora czasopisma”. Zdaniem Sądu powoływanie się na list Tereszczenki, korespondencję z hrabią Lerchenfeldem czy opinię, że Lednicki był przeciwny tworzeniu polskiej armii w Rosji nie dawały podstaw do wyrażenia na łamach prasy opinii o zdradzie. Społeczeństwo polskie przed 1918 rokiem dzieliło się na szereg, czasami zwalczających się, orientacji politycznych. Nie było jedno-

66 Odpowiedź na skargę apelacyjna, [w:] Akta sędziego śledczego Sądu Okręgowego $w$ Warszawie, k. 191v.

67 Ibidem, k. 200.

68 Wyrok $w$ imieniu Rzeczypospolitej Polskiej, Materiały Aleksandra Lednickiego, PAN. AW, sygn. III - 123, teczka 22, k. 11. 
litej linii w przedmiocie rozwiązania sprawy polskiej, zaś każda koncepcja w opinii głoszących ją polityków zakładała największe korzyści dla Polski. Przed wskrzeszeniem Rzeczypospolitej Polskiej, zdaniem Sądu powołującego się na orzeczenie kompletu II Sądu Najwyższego z 17 października 1919 roku, od 1815 roku na części jej obszaru istniało Państwo Polskie pod nazwą Królestwa Polskiego, które mogło stać się przedmiotem zdrady ${ }^{69}$. Jednakże w okresie pierwszej wojny światowej nie było instytucji, które mogłyby być uważane za prawowite organy „niezależnej woli i władzy zwierzchniej całego Narodu". Nie miały charakteru rządów ogólnopolskich, mimo że niektóre ugrupowania czy odłamy społeczeństwa polskiego za takie je uważały. Sąd wskazał na Tymczasową Radę Stanu, Radę Regencyjną oraz Komitet Narodowy Polski. Dlatego też działania polskich polityków, sprzeczne $z$ ogólną linią wskazanych instytucji, nie mogły być uważane za zdradę, gdyż „nie mogła być sprzeczną z wolą organu, uprawnionego do rządzenia i prowadzenia polityki w imieniu Państwa i Narodu Polskiego, jako całości, ponieważ takiego organu przed końcem 1918 roku nie było". Nawet gdyby była szkodliwa, biorąc pod uwagę kryterium obiektywne, dla interesów kraju, a uprawiana w dobrej wierze, w celu „pchnięcia” sprawy polskiej na właściwe tory, to o zdradzie mowy być nie mogło $^{70}$. Według sądu zdrada główna wystąpiłaby, gdyby Lednicki

69 Zob. C. Berezowski, Powstanie państwa polskiego $w$ świetle prawa narodów, Warszawa 2008, s. 97; w orzeczeniu z 1919 roku Sąd Najwyższy uznał, że odrębność państwowa Królestwa Polskiego nigdy nie wygasła ani w poczuciu narodu polskiego, ani w obliczu prawa międzynarodowego. Występowało jako państwo odrębne w rozumieniu prawa narodów, złączone z Cesarstwem Rosyjskim węzłem unii, mające własną państwowość uznawaną przez międzynarodową społeczność. Z kolei w orzeczeniu z 29 oraz 30 września 1922 r. Sąd Najwyższy oświadczył, że błędem historycznym i prawnym było twierdzenie, że państwo polskie przestało istnieć po 1795 roku. Państwa upadają, gdy społeczeństwo traci poczucie odrębności, gdy zmienia się psychika społeczna mieszkańców, gdy znika tradycja i chęć podtrzymywania dawnych wierzeń czy dążeń. Ludność, terytorium oraz władza nie zawsze muszą być ze sobą stale związane i na pewno nie stanowią najważniejszego kryterium.

70 Wyrok $w$ imieniu Rzeczypospolitej Polskiej, Materiały Aleksandra Lednickiego, k. 11v. 
„uczynił coś świadomie na szkodę powstającej z gruzów Polski, gdyż najistotniejszą cechą tej zbrodni jest zły zamiar sprawcy szkodzenia własnemu Państwu, względnie Narodowi, zamiar bezpośredni, czy też ewentualny”. A tego, a więc współdziałania z wrogami Polski, Wasilewski w trakcie postępowania nie udowodnił. Sąd apelacyjny podkreślił także, że list Lednickiego do hrabiego Lerchenfelda nigdy do adresata nie został wysłany, stanowił jedynie projekt, o czym Wasilewski musiał wiedzieć bądź z łatwością mógł to uczynić. Lednicki nie denuncjował nikogo ze zwracających się do niego o pomoc Polaków wojskowych, udających się na front murmański. Wręcz przeciwnie, pomagał im wielokrotnie. Zresztą fakt werbowania Polaków przebywających w Rosji do armii sojuszniczych był powszechnie znany tak władzom niemieckim, jak bolszewickim ${ }^{71}$. Wasilewski nie udowodnił, że miał obiektywnie dostateczną podstawę do uważania rozgłoszonej przez siebie informacji za prawdziwą. Tym samym nie wystarcza subiektywne przekonanie o prawdziwości zarzutu. To nie usprawiedliwiało Wasilewskiego ani życiowo, ani $z$ punktu widzenia obowiązującej wówczas ustawy karnej jak i tłumaczenia się, że „imputowany mu czyn popełnił nie z pobudek, wypływających z prywaty osobistej lub partyjnej, lecz w interesie publicznym i w wykonaniu pełnionego przezeń obowiązku publicysty. Najszlachetniejsze nawet pobudki nie mogą usprawiedliwić [...] lekkomyślnego traktowania czci osobistej obywatela; a tym bardziej karygodną jest ta lekkomyślność, gdy rzuca się oskarżenie o tak ciężką i ohydną zbrodnię, jaką jest zdrada własnego kraju, obywatelowi, który [...] jako działacz społeczny polski na obczyźnie wykazał się wobec społeczeństwa polskiego wybitnymi i zgoła nieprzeciętnymi zasługami”. Wasilewski nie mógł powoływać się także na fakt, że zarzut postawiony Lednickiemu, został zaczerpnięty z periodyku „Myśl Niepodległa”. Wszelkie przedruki bowiem znieważające kogokolwiek nie zwalniają redaktora naczelnego $z$ obowiązku sprawdzenia, czy dana informacja jest zgodna z rzeczywistością. Wasilewski zresztą inkryminacje zdrady znacznie rozszerzył i skonkretyzował, nie popierając tego żadnymi dowodami.

71 Ibidem, k. 12. 
Sąd apelacyjny uchylił wyrok uniewinniający Wasilewskiego wydany w pierwszej instancji. Skazał redaktora „Gazety Warszawskiej”, na mocy art. $533 \mathrm{KK}$ za zniesławienie na karę dwóch miesięcy aresztu oraz na zapłatę grzywny w wysokości trzystu złotych, które jednak, z uwagi na ustawę o amnestii z 6 lipca 1923 roku, nie zostały wykonane. Uzasadniając wymiar kary, sąd wziął pod uwagę całokształt ustalonych okoliczności, łagodzących winę oskarżonego, jego wcześniejszą niekaralność oraz długi czas, jaki upłynął od wydrukowania artykułu do wydania orzeczenia sądowego. Do tego dochodził również okres, w jakim znajdowało się państwo polskie, które było widownią „niezwykle obostrzonych i nie przebierających w środkach walk partii i obozów politycznych, a w prasie przejaskrawione zarzuty i inwektywy pod adresem przeciwników politycznych były niemal powszechne, nie spotykając należytej reakcji we wciągniętym w wir tych walk i roznamiętnionym również do najwyższego stopnia społeczeństwie" 72 .

Pełnomocnik Zygmunta Wasilewskiego Stanisław Kijeński złożył 28 maja 1925 roku skargę kasacyjną do Sądu Najwyższego. Nie zgadzał się $z$ orzeczeniem sądu apelacyjnego w kwestii interpretacji podmiotowości państwa, które uzyskiwało osobowość prawną wtedy, gdy zostało „upostaciowione” w państwowej władzy zwierzchniej jako organie swojej woli. Taka egzegeza nie odpowiadała istocie wyroku Sądu Najwyższego z 1919 roku, a także definicjom nauki oraz faktom historycznym. W opinii Kijeńskiego bowiem źródłem woli państwowej, wyrażonej formalnie czy też potencjalnie, był naród. Argumentował: „On jest czynnikiem suwerenności państwowej. Ten czynnik woli w życiu narodu historycznego, który pragnie żyć i dąży do niepodległości, może być utajony, ale on jest, z całą podstawą świadomości historycznej, a im bardziej jest zatajony [...], tym silniej występuje w życiu moralnym obywateli i mając oparcie w ich sumieniu, tym wrażliwszy się staje na zdradę. Ten fakt cudowny opancerzenia swej woli życia, jako zadatku przyszłej państwowości, wrażliwą na zdradę moralnością obywatelską, pozwolił Polsce przetrwać lata niewoli i nie zboczyć $z$ drogi historycznej. Nie przedawnione prawa Polski do życia, nie wygasła wola życia - to

72 Ibidem, k. 12v. 
były podstawowe artykuły konstytucji Polaka do końca 1918"73. W innym miejscu zaznaczał: „Wyrok Sądu Apelacyjnego pominął, jak gdyby nieistniejący, cały dorobek dowodowy procesu i zawiesił twierdzenie swoje w powietrzu bez żadnego uzasadnienia faktycznego i logicznego. Sąd Apelacyjny doszedł do wniosku kary dla Wasilewskiego $\mathrm{w}$ drodze dedukcji $\mathrm{z}$ tez, $\mathrm{z}$ góry postawionych, traktując i całą sprawę i osoby abstrakcyjnie, bez związku z prawdą dziejową, moralnie obowiązującą społeczeństwo polskie, a nawet $z$ prawdą, psychologiczną. [...] nie można oceniać jego czynu teoretycznie $z$ przesłanek dowolnie dobranych. Sprawa sama w życiu nie była zagadnieniem teoretycznym, żywo wstrząsnęła opinią i uczuciami społeczeństwa" ${ }^{44}$. Orzeczenie ądu apelacyjnego obrażało i w znacznym stopniu deprymowało poczucie sprawiedliwości i prawdy ${ }^{75}$. Na słowa te swoją odpowiedź na skargę konstytucyjną złożył także mecenas Eugeniusz Śmiarowski, który uznał, że pismo oskarżonego nie zawierało w swojej treści zarzutów natury kasacyjnej, a jedynie wywody natury dziennikarsko-polemicznej. Pisał: „Rzecz prosta, że opinia skargi kasacyjnej w tym lub w innych ustępach w podatnie apodyktyczny sposób wyrażono, będąca na ogół odbiciem ciasnego poglądu partyjnego, oburzająca się na Sąd Apelacyjny na niedostateczny pietyzm wobec poczynań stronnictwa narodowo - demokratycznego i jej poszczególnych przywódców, że taka opinia nie jest jeszcze normą ustawową, która by była w wyroku przez Sąd pogwałcona, a niezgodność wyroku Sądu z poglądami tej lub innej partii politycznej, chociażby najbardziej w swoich wyznawców nieomylnej, nie jest jeszcze ustawowym powodem do skasowania wyroku"76. Dlatego też zdaniem Śmiarowskiego powinna być oddalona. Ostatecznie Sąd Najwyższy wyroku drugiej instancji nie skasował, a orzeczenie $z 14$ maja 1925 roku zatwierdził ${ }^{77}$. W uzasadnieniu, opierając się na przesłankach relatywizmu filozo-

73 Skarga kasacyjna, [w:] Akta sędziego śledczego Sądu Okręgowego $w$ Warszawie, k. 206v

74 Ibidem, k. $214 \mathrm{v}$.

75 Ibidem, k. $215 \mathrm{v}$.

76 Odpowiedź na skargę kasacyjna, [w:] Akta sędziego śledczego Sądu Okręgowego $w$ Warszawie, k. 217.

77 W. Lednicki, Aleksander Lednicki (oszczerstwa i prawda), s. 87. 
ficznego, sędziowie zaznaczyli, że działalność Aleksandra Lednickiego oraz Zygmunta Wasilewskiego powodowała znaczną rozbieżność w ich poglądach politycznych, która nie upoważniała w żaden sposób do słownego obrażania przeciwnika ${ }^{78}$. Po tych wydarzeniach i permanentnej nagonce ze strony obozu narodowego Lednicki odsunął się od działalności politycznej, nie rezygnując jednak z wykonywania zawodu adwokata ${ }^{79}$. Podsumowując ten okres, pełen przepychanek i krytyki, Wacław Lednicki na kartach swoich wspomnień pisał: „Często zastanawiałem się nad tym, skąd ta straszna nienawiść [...]. Sądzę, że zadecydowała tu absolutna klęska obozu narodowo-demokratycznego w Rosji, klęska na wszystkich polach. A zwyciężył mój ojciec nie tylko osobiście, i tego narodowa demokracja nie mogła darować. Nie chodziło tu pewno nawet o interesy osobiste. Ropa nienawiści sączyła się z głębszych dziedzin: zwyciężyła ideologia, która od $A$ do $Z$ pozostawała w niezgodzie z przestarzałym, szowinistycznym, mieszczańskim poglądem na swiat. $Z$ jednej strony powiewały ideały głoszone przez naszych wieszczów, $z$ drugiej szczerzyła zęby polityczna dulszczyzna [...]. Pogodzenie rozsadzającego państwo polskie nacjonalizmu Dmowskiego $z$ ideałami powszechnej wolności, którym ojciec służył przez całe swoje życie - nie było możliwe, i stąd po zwycięstwie w Rosji ojciec spotkał się w Polsce $z$ ostracyzmem, który politycznie go zniszczył" ${ }^{\circ}$.

Sprawa Zygmunta Wasilewskiego poruszyła opinię publiczną odrodzonej Rzeczypospolitej Polskiej. Zasada wolności słowa potrzebowała definicji i wyznaczenia granicy jej nienaruszalności. Słowo pisane miało ogromną moc, a wypowiedziane piórem redaktora jednego z największych czasopism prawicowych ówczesnej Polski musiało nieść za sobą określone konsekwencje. Niewątpliwie cały trwający ponad pięć lat proces miał podłoże polityczne i ideologiczne, a głównym aktorem, zresztą nie po raz pierwszy w okresie dwudziestolecia międzywojennego, stał się polityk związany z obo-

78 Z. Wasilewski, Pokolenia $w$ służbie narodu, s. 26.

79 W. Toporowicz, Lednicki Aleksander, [w:] Polski Słownik Biograficzny, t. XVI/4, z. 71, Wrocław-Warszawa-Kraków-Gdańsk 1971, s. 612.

80 W. Lednicki, Pamiętniki, t. II, Londyn 1967, s. 624-625. 
zem Narodowej Demokracji. Kompromitacją ówczesnego wymiaru sprawiedliwości był wyrok sądu okręgowego, który wbrew zebranemu materiałowi dowodowemu wydał orzeczenie uniewinniające Wasilewskiego. Instancyjność postępowania pozwoliła jednak na sprawiedliwe osądzenie winnego i tym samym oczyszczenie Lednickiego $z$ zarzucanych mu czynów.

\section{SUMMARY}

\section{Case of Zygmunt Wasilewski - Aleksander Lednicki's trial for libel}

Case of Zygmunt Wasilewski raised the issue of public opinion reborn Polish Republic. The principle of freedom of speech, need definitions and the delimitation of its integrity. The written word had enormous power, and the editor said the pen of one of the largest right-wing magazine of contemporary Polish "Gazety Warszawskiej", had to have some specific consequences. Undoubtedly, the whole trial, which lasted more than five years (1920-1925), had a political and ideological base, and the main actor, and not for the first time in the interwar period, became a politician associated with the camp of the National Democracy. Embarrassment for the then justice of the District Court's judgment was that in spite of harvested evidence, issued a judgment of acquittal Wasilewski, stating that libel could not be said. Trial an instance, but allowed for a fair judgment, and thus guilty of Alexander Lednicki purification of the alleged offense, that is treason to the Polish state.

Key-words: libel, National Democracy 